\title{
Kearifan Lokal Nusa Tenggara Timur sebagai Sumber Bahan Ajar Menulis Teks Eksplanasi untuk Siswa Kelas XI
}

\author{
Petronela $\mathrm{Mau}^{1}$, Nurchasanah ${ }^{1}$, Martutik ${ }^{1}$ \\ ${ }^{1}$ Pendidikan Bahasa Indonesia-Universitas Negeri Malang
}

\begin{tabular}{l}
\hline \hline INFO ARTIKEL \\
\hline Riwayat Artikel: \\
Diterima: 03-05-2019 \\
Disetujui: 28-05-2019 \\
\hline
\end{tabular}

\section{Kata kunci:}

local culture; teaching materials; explanatory text; kearifan lokal; bahan ajar; teks eksplanasi

\section{Alamat Korespondensi:}

Petronela Mau

Pendidikan Bahasa Indonesia

Universitas Negeri Malang

Jalan Semarang 5 Malang

E-mail: maupetronela666@gmail.com

\section{ABSTRAK}

Abstract: The purpose of this development research is to produce explanatory text teaching materials based on local wisdom of East Nusa Tenggara for class XI students. Local wisdom-based teaching materials can be used as a source of learning. Teaching material products produced using the $\mathrm{R} \& \mathrm{D}$ development model. The validation results show that the product feasibility reaches $83 \%$ with eligible criteria. Field test results show an increase in learning outcomes after using teaching materials.

\begin{abstract}
Abstrak: Penelitian pengembangan ini bertujuan untuk menghasilkan bahan ajar teks eksplanasi berbasis kearifan lokal Nusa Tenggara Timur untuk siswa kelas XI. Bahan ajar berbasis kearifan lokal dapat dijadikan salah satu sumber belajar. Produk bahan ajar yang dihasilkan mengunakan model pengembangan R\&D. Hasil validasi menunjukkan bahwa kelayakan produk mencapai $83 \%$ dengan kriteria layak. Hasil uji lapangan menunjukkan adanya peningkatan hasil belajar setelah menggunakan bahan ajar.
\end{abstract}

Bahan ajar merupakan salah satu komponen penting dalam kegiatan belajar mengajar. Upaya peningkatan mutu proses dan hasil belajar serta memperluas kesempatan pemerolehan pendidikan dapat diwujudkan melalui bahan ajar (Depdiknas, 2008). Bahan ajar terdiri atas pengetahuan dan keterampilan yang harus dipelajari siswa dalam rangka pencapai standar kompetensi yang telah ditentukan. Sesuatu yang digunakan guru atau siswa untuk memudahkan belajar bahasa, peningkatkan pengetahuan, dan pengalaman berbahasa disebut bahan ajar (Darmawan, 2012). Selain itu, bahan ajar idealnya dapat membantu siswa dalam memenuhi standar kompetensi lulusan yang telah ditetapkan (Mascita \& Rosmiyati, 2018). Materi yang disajikan dalam bahan ajar berupa unit-unit pembelajaran sehingga bahan ajar dijadikan sarana belajar yang praktis. Pada dasarnya, bahan ajar berlandasakan kebutuhan siswa yang susunannya dalam bentuk unit-unit atau latihan khusus sesuai dengan kurikulum (Budi, 2018).

Menulis menjadi unsur terpenting dalam pembelajaran karena menulis memudahkan siswa berpikir secara kritis. Selain itu, tulisan dapat membantu menjelaskan sesuatu yang dipikirkan. Menulis menitikberatkan pada pengalihan bahasa lisan ke dalam bentuk tertulis (Pateda, 1989). Aktivitas menulis sesungguhnya membantu siswa secara aktif dalam pengembangan keterampilan bahasa. Pola-pola bahasa yang diketahui dan dirasakan dihasilkan melalui keterampilan berbahasa secara aktif. Keterampilan menulis diperoleh dengan proses berlatih dan belajar sehingga dapat dijadikan kebiasaan (Owon, 2017).

Berlatih menulis memudahakan seseorang untuk berani menuangkan ide dan mengembangkan tulisan berdasarkan ide. Menulis bertujuan untuk memberikan informasi bagi pembaca. Terdapat enam tujuan yang akan dicapai oleh penulis, yaitu (1) pembaca diajak untuk ikur berpikir dan berimajinasi, (2) menyampaikan kepada pembaca tentang hal yang diberitakan, (3) membat pembaca berpendapat, (4) melatih pemahaman pembaca, (5) mengajak pembaca memahami isi karangan, dan (6) nilai-nilai yang ditampilkan dalam tulisan seperti nilai-nilai kehidupan dapat dihayati oleh pembaca sehingga dapat dijadikan pedoman hidup dalam bermasyarakat (Akhadiah, 1992).

Pengembangan bahan ajar menulis teks eksplanasi merupakan langkah ampuh dalam mengatasi kesulitan sumber belajar teks eksplanasi. Kesulitan ini disebabkan teks eksplanasi belum ada pada kurikulum KTSP. Pembelajaran kurikulum 2013 menerapkan pembahasan pada pelajaran bahasa Indonesia yaitu menulis teks eksplanasi. Teks eksplanasi menghubungkan suatu bacaan dengan keadaan alam dan sosiokultural yang terjadi di lingkungan masyarakat. Teks eksplanasi memiliki struktur, yaitu pernyataan umum, deretan penjelas, dan interpretasi. Bagaimana dan mengapa kejadian/peristiwa terjadi menjadi acuan dalam memahami teks eksplanasi. Teks yang memuat penjelasan mengenai proses terjadinya kejadian sosial, alam, budaya, dan ilu pengetahuan disebut teks eksplanasi (Rimayanti dan Jaja, 2018). Teks ini bertujuan menjelaskan kepada pembaca tentang suatu fenomena yang terjadi. 
Pengembangan bahan ajar ini berbasis kearifan lokal. Alasan penggunaan kearifan lokal dalam bahan ajar ini adalah untuk memudahkan siswa memahami materi. Selain itu, penyajian materi disertai contoh konkret yang dialami siswa. Bahan ajar berbasis kearifan lokal Nusa Tenggara Timur diharapkan mampu menumbuhkan kreativitas siswa dalam menulis teks eksplanasi. Selain itu, mempelajari kearifan lokal dapat membantu siswa mengenal dan akhirnya melestarikan tradisi yang menjadi pedoman hidup. Dengan demikian, diharapkan bahan ajar berbasis kearifan lokal ini dapat menciptakan situasi belajar kondusif dan bermakna sehingga mampu memberikan keterampilan dan pengetahuan bagi siswa. Kearifan lokal dinilai linear dalam dunia pendidikan sebab lingkungan belajar diciptakan alamiah mampu menjadikan pembelajaran efektif. Selain itu, anak mengalami sendiri apa yang dipelajarinya dapat membuat pembelajaran lebih bermakna dan menyenangkan (Owon, 2017).

Pengembangan bahan ajar ini didasarkan pada kemampuan siswa yang kurang memadai dalam proses belajar teks eksplanasi. Pembelajaran mengenai teks eksplanasi secara spesifik terdapat di dalam silabus kurikulum 2013 tingkat SMA khusunya kelas XI. Salah satu pokok pembahasannya adalah menulis teks eksplanasi. Selain itu, sumber belajar teks eksplanasi kurang sehingga perlu menambah buku penunjang seperti bahan ajar yang dijadikan suplemen. Penelitian Pengembangan ini memiliki dua tujuan. Tujuan pertama, yaitu menghasilkan bahan ajar menulis teks eksplanasi berbasis kearifan lokal Nusa Tenggara Timur. Tujuan kedua, yaitu menguji efektivitas bahan ajar yang dihasilkan.

\section{METODE}

Penelitian ini dilakukan dengan menggunakan model Research \& Development. Model penelitian ini diadaptasi dari prosedur penelitian yang dikemukakan oleh Sugiyono (2016). Dalam penelitian pengembangan R\&D ini ditetapkan 10 langkah yang dijalankan untuk menyusun produk. Namun, tahap-tahap umum model R \& D diadaptasi sesuai dengan kebutuhan pengembangan bahan ajar. Tahap model pengembangan ini diadaptasi menjadi tujuh tahap, yaitu (1) pengumpulan informasi awal, (2) perencanaan, (3) pengembangan bahan ajar, (4) melakukan uji ahli dan praktisi, (5) revisi produk awal, (6) uji lapangan terbatas, dan (7) penyempurnaan produk akhir. Alasan hanya digunakan tujuh langkah karena faktor keterbatasan materi. Selain itu, disebabkan oleh keterbatasan waktu, tenaga, dan perizinan di lapangan. Tahap revisi produk hanya dilakukan dua kali yaitu setelah uji validasi dan uji lapangan terbatas.

Sumber data dalam penelitian ini, yaitu ahli menulis, ahli bahan ajar, praktisi, dan siswa. Pengumpulan data dilakukan dengan menggunakan instrumen angket penilaian, pedoman wawancara, dan lembar observasi. Angket diberikan kepada ahli, praktisi, dan siswa. Wawancara terstruktur dilakukan pada tahap prapengembangan kepada praktisi, sedangkan wawancara bebas dilakukan ketika uji validasi untuk memperoleh komentar dan masukan yang digunakan dalam revisi produk. Dalam mencatat hal yang diamati dalam pelaksanaan pembelajaran menggunakan bahan ajar digunakan lembar observasi. Data penelitian ini berupa data numerik dan data verbal. Data skor yang diperoleh dari instrumen angket penilaian disebut data numerik. Data verbal dibedakan menjadi data tertulis dan data lisan. Data verbal tertulis berupa catatan dan saran yang dituliskan oleh validator ahli dan praktisi, sedangkan data verbal lisan berupa informasi yang disampaikan secara lisan ketika uji validasi.

Analisis data dilakukan secara kualitatif dan kuantitatif. Analisis kualitatif dilakukan untuk menganalisis data yang berasal dari wawancara dan angket penilaian yang berupa komentar dan saran perbaikan. Langkah-langkah yang dilakukan untuk melaksanakan analisis kualitatif meliputi empat aktivitas, yaitu (1) mengumpulkan data tertulis dari hasil wawancara, lembar observasi, dan data tertulis di angket, (2) mentranskripkan data lisan yang ditemukan, (3) menganalisis data, dan (4) membuat simpulan berdasarkan data yang telah dianalisis. Hasil analisis diperoleh sebagai bahan pertimbangan terhadap produk yang dikembangkan.

Analisis kuantitatif digunakan untuk menganalisis data kuantitatif yang diperoleh dari hasil validasi ahli, validasi praktisi, dan angket hasil uji lapangan. Analisis data kuantitatif dilakukan dengan empat langkah, yaitu (1) nilai dari hasil uji coba produk dan uji validasi ahli maupun praktisi yang menjadi data dikumpulkan, (2) menghitung data yang telah terkumpul, (3) menganalisis data dengan cara mempresentasikan dengan rumus, dan (4) menyimpulkan hasil validasi dalam bentuk persentase yang dicocokan dengan kriteria produk.

Data kuantitatif yang diperoleh dari pretes dan postes dianalisis uji beda dengan digunakannya uji-t sampel berpasangan melalui program SPSS 16.0. Uji-t digunakan untuk melihat ada atau tidak ada perbedaan hasil belajar sesudah penggunaan bahan ajar. Rumus yang digunakan adalah t-test dengan teknik paired samples test. Taraf signifikansi yang digunakan, yaitu 0,05. Uji normalitas data dilakukan untuk mengetahui persebaran datanya nomal atau tidak normal. Data dikatakan normal jika taraf signifikansi lebih dari 0,05.

\section{HASIL}

Pada bagian ini dijabarkan tiga hal yang berkaitan dengan temuan, yaitu (1) deskripsi produk, (2) hasil uji, dan (3) revisi produk. Ketiga hal tersebut dijabarkan sebagai berikut. 


\section{Deskripsi Produk}

Produk yang dihasilkan berupa bahan ajar yang berjudul Menulis Teks Eksplanasi Berbasis Kearifan Lokal Nusa Tenggara Timur untuk Siswa Kelas XI. Bahan ajar ini berwujud buku cetak. Deskripsi produk terbagi dalam empat bagian, meliputi deskrispi isi, penyajian, bahasa, dan tampilan.

Pertama, deskripsi isi bahan ajar. Isi bahan ajar Menulis Teks Eksplanasi Berbasis Kearifan Lokal Nusa Tenggara Timur mencakup empat kompetensi dasar. Empat kompetensi dasar, yaitu (1) mengidentifikasi informasi (pengetahuan dan urutan kejadian) dalam teks eksplanasi lisan dan tulis, (2) mengonstruksi informasi (pengetahuan dan urutan kejadian) dalam teks eksplanasi secara lisan dan tulis, (3) menganalisis struktur dan kebahasaan teks eksplanasi, serta (4) memproduksi teks eksplanasi secara lisan atau tulis dengan memperhatikan struktur dan kebahasaan (Kemendikbud, 2017). Keempat kompetensi dasar ini dijabarkan dalam empat unit bahasan. Bahan ajar yang dikembangkan ini berbasis kearifan lokal Nusa Tenggara Timur. Bahan ajar ini berisi meteri, contoh, dan latihan yang menuntun siswa mengenal hingga menulis teks eksplanasi.

Kedua, deskripsi penyajian bahan ajar. Sistematika penyajian bahan ajar ini, meliputi bagian pendahuluan, isi, dan penutup. Bagian pendahuluan terdiri atas kata pengantar, daftar isi, kompetensi inti-kompetensi dasar, dan peta konsep. Bagian isi menggunakan pendekatan pedagogik genre. Pendekatan pedagogik genre memiliki empat langkah, yaitu (1) membangun konteks, (2) pemodelan, (3) latihan terbimbing, dan (4) latihan mandiri. Pendekatan pedagogik genre ini diterapkan dalam empat unit dengan tema yang beragam sesuai dengan kearifan lokal yang ditampilkan. Unit satu bertema mengekspresikan diri sebagai masyarakat yang ramah melalui tarian. Dalam unit ini berisi mengenal teks eksplanasi. Unit dua bertema menjaga dan memelihara alam sebagai sumber kehidupan dan rasa syukur kepada pencipta. Dalam unit ini membangun kembali teks eksplanasi sesuai dengan pemahaman setelah membaca teks. Unit tiga bertema kebersamaan dalam persaudaraan melalui tradisi. Dalam unit dibahas struktur dan ciri kebahasaan teks eksplanasi. Unit empat bertema mengekspresikan sikap hidup masyarakat NTT yang bertanggung jawab melalui mahar dan kain adat. Dalam unit ini, siswa dilatih menulis dan menyunting teks eksplanasi. Selain itu, di setiap unit dilengkapi dengan rangkuman, evaluasi, dan refleksi. Bagian penutup terdiri atas ujian akhir, glosarium, dan daftar rujukan.

Ketiga, deskripsi bahasa bahan ajar. Penggunaan bahasa formal berdasarkan pedoman umum EYD diutamakam dalam bahan ajar ini. Selain itu, bahan ajar ini juga menggunakan bahasa yang komunikatif. Kalimat yang digunakan dalam petunjuk latihan sederhana sehingga mudah dipahami. Bahasa yang digunakan jelas dan efektif sesuai dengan tingkatan usia siswa kelas XI.

Keempat, deskripsi tampilan bahan ajar. Bahan ajar ini mempunyai kesesuaian tampilan ilustrasi dengan isi bahan ajar yang menampilkan kearifan lokal Nusa Tenggara Timur. Gambar dalam bahan ajar diatur secara baik sehingga dapat memperjelas bacaan. Selain itu, bahan ajar diatur dengan tata letak, jenis, ukuran huruf, komposisi, dan ilustrasi sehingga menjadi menarik.

\section{Hasil Uji}

Tahapan selanjutnya setelah penyusunan bahan ajar ini adalah penilaian oleh validator. Validasi ahli dilakukan oleh ahli menulis, bahan ajar, dan praktisi. Validasi ahli dilakukan untuk memperoleh komentar dan catatan yang berguna untuk perbaikan terhadap produk yang dikembangkan. Hasil rekapitulasi uji kevalidan produk bahan ajar sebesar 83\%. Berdasarkan data rekapitulasi kevalidan produk menunjukkan kriteria layak dan siap diimplementasikan dalam pembelajaran. Adapun rincian dari masing-masing aspek dijelaskan sebagai berikut.

Pertama, kelayakan isi. Kelayakan isi bahan ajar ini mendapat skor $92 \%$, sebelumnya mendapatkan skor $60 \%$ dari ahli pembelajaran menulis, $75 \%$ dari ahli bahan ajar sebelumnya 60\%, $86 \%$ dari praktisi, dan $85 \%$ dari siswa. Rata-rata skor kelayakan isi sebesar $85 \%$ diberikan oleh subjek uji. Skor ini menunjukkan kualifikasi sangat layak. Oleh sebab itu, isi produk ini dapat diimplementasikan dalam bahan ajar.

Kedua, kelayakan penyajian bahan ajar. Kelayakan penyajian bahan ajar ini mendapat skor 80\%, $80 \%$ dari ahli bahan ajar, $80 \%$ dari praktisi, dan $85 \%$ dari siswa. Rata-rata skor kelayakan Penyajian diberikan subjek uji sebesar $81 \%$. Skor ini menunjuklan kualifikasi layak, maka penyajian produk ini dapat diimplementasikan dalam bahan ajar.

Ketiga, kelayakan bahasa bahan ajar. Kelayakan bahasa bahan ajar ini mendapat skor $80 \%$, dari ahli pembelajaran menulis, $75 \%$ dari ahli bahan ajar, $80 \%$ dari praktisi, dan $86 \%$ dari siswa. Rata-rata skor kelayakan bahasa sebesar $80 \%$ yang diberikan oleh subjek uji. Skor ini menunjukkan kualifikasi layak sehingga bahasa produk ini dapat diimplementasikan dalam bahan ajar.

Keempat, kelayakan tampilan bahan ajar. Kelayakan tampilan bahan ajar ini mendapat skor $88 \%$, dari ahli pembelajaran menulis, $77 \%$ dari ahli bahan ajar, $95 \%$ dari praktisi, dan $85 \%$ dari siswa. Rata-rata skor kelayakan tampilan diberikan subjek uji sebesar $86 \%$. Skor ini menunjukkan kualifikasi sangat layak. Oleh karena itu, tampilan produk ini dapat diimplementasikan dalam bahan ajar.

Uji keefektifan bahan ajar dilakukan untuk mengetahui keefektifan penggunaan bahan ajar menulis teks eksplanasi berbasis kearifan lokal Nusa Tenggara Timur. Desain yang digunakan untuk menguji pengaruh penggunaan produk yang dikembangkan terhadap hasil pembelajaran menulis teks eksplanasi ialah desain praeksperimen. Desain tersebut terdiri atas dua kegiatan pengujian, yaitu pretes dan postes pada kelompok tunggal (tanpa kelas kontrol). Uji keefektifan produk ini dilakukan pada 17 siswa dalam satu kelas. Hasil uji keefektifan produk diketahui setelah pretes dan postes selesai dilakukan. Maka 
diperoleh skor siswa yang menunjukkan kemampuan menulis teks eksplanasi sebelum dan setelah diberi perlakuan menggunakan bahan ajar teks eksplanasi berbasis kearifan lokal NTT. Data pretes dan postes dianalisis melalui uji normalitas data dan uji beda. Hasil yang diperoleh digunakan untuk menentukan kenormalan persebaran data pretes dan postes dan perbedaan hasil pretes dan postes. Data uji keefetifan dianalisis sesuai dengan uji normalitas dan uji beda. Berdasarkan hasil perhitungan uji normalitas data, diketahui bahwa hasil uji Kolmogorov-Smirnov data pretes sebesar 0,048 dan hasil uji normalitas data postes sebesar 0,068. Persebaran data dikatakan normal jika hasil uji normalitas lebih besar dari 0,05. Hasil perhitungan data pretes dan postes lebih besar dari 0,05 sehingga data berdistribusi normal.

Berdasarkan uji normalitas data yang berdistribusi normal, dilakukan uji beda dengan teknik paired sampled t-test. Penggunaan uji-t sampel berpasangan dalam analisis ini karena data yang dihasilkan ialah sepasang data yang memiliki subjek, yaitu skor hasil pretes dan skor hasil postes. Jika nilai signifikansi (2-tailed) $<0,05$, maka terdapat perbedaan yang signifikan antara hasil kemampuan menulis teks eksplanasi berbasis kearifan lokal NTT pada data pretes dan postes. Apabila nilai nilai signifikansi (2-tailed) > 0,05, maka tidak terdapat perbedaan yang signifikan antara data pretes dan postes. Dari tabel di atas dapat diketahui bahwa nilai signifikansi (2-tailed) $<0,05$ sehingga dapat disimpulkan bahwa terdapat perbedaan antara data pretes dan postes. Dengan demikian, terdapat peningkatan yang signifikan pada hasil belajar setelah menggunakan bahan ajar yang dikembangkan. Oleh sebab itu, produk ini dapat diimplementasikan.

\section{Revisi Produk}

Revisi ini dilakukan berdasarkan data verbal dari ahli bahan ajar dan ahli menulis. Adapun saran dan masukan dari ahli menulis meliputi (a) perbaiki teks bacaan, (b) variasikan latihan atau evaluasi, dan (c) perhatikan dengan cermat latihan penalaran pola sebab-akibat. Saran dari ahli bahan ajar, yaitu (a) terdapat beberapa teks yang masih didominasi deskripsi sehingga perlu ditekankan pada aspek eksplanasi, (b) terdapat soal yang penggunaan bahasanya terlalu teoretis, perlu diganti dengan bahasa yang sederhana dalam petunjuk pengerjaan soal, dan (c) konsep kegiatan menulis terbimbing masih didominasi keterampilan membaca sehingga perlu divariasikan dengan kegiatan menulis seperti melengkapi, mengubah, dan melanjutkan.

\section{PEMBAHASAN}

\section{Isi Bahan Ajar}

Bahan ajar adalah suplemen belajar yang berisi bahan yang diperlukan dalam pencapai tujuan pembelajaran sesuai kompetensi. Oleh karena itu, isi bahan ajar harus merumuskan materi pokok yang sesuai dengan kompetensi yang akan dicapai. Bahan ajar ini didasarkan pada empat kompetensi dasar, yaitu 3.3 mengidentifikasi informasi (pengetahuan dan urutan kejadian) dalam teks eksplanasi lisan dan tulis, 4.3 mengonstruksi informasi (pengetahuan dan urutan kejadian) dalam teks eksplanasi secara lisan dan tulis, 3.4 menganalisis struktur dan ciri bahasa, serta 4.4 memproduksi teks eksplanasi secara lisan atau tulis dengan memperhatikan struktur dan ciri kebahasaan (Kemendikbud, 2017).

Isi bahan ajar meliputi keakuratan materi, kedalaman materi, dan kelengkapan materi. Pada aspek keakuratan materi bahan ajar, hal yang diubah adalah teori teks eksplanasi yang diaplikasikan pada bacaan-bacaan yang ditampilkan. Bacaan yang menjadi contoh teks eksplanasi harus benar-benar mengikuti struktur teks eksplanasi sehingga tidak terkecoh pada jenis teks lain. Teori teks eksplanasi berupa struktur teks eksplanasi. Selain itu, isi bahan ajar mengandung kearifan lokal. Nilai kearifan lokal dapat membentuk sistem kepercayaan, budaya, norma dan diekspresikan di dalam tradisi yang tertanam dalam diri siswa harus terkandung dalam bahan ajar (Mascita, 2018).

Pada aspek kedalaman materi bahan ajar ini telah direvisi dengan menambah latihan soal sehingga melatih daya pikir siswa. Latihan soal yang ditampilkan mengasah kemampuan siswa berpikir. Selain latihan soal menulis teks eksplanasi, bahan ajar ini juga dilengkapi dengan soal UN dan SBMPTN. Bentuk soal yang bervariasi ini bertujuan sebagai pembiasaan terhadap soal-soal yang akan dihadapi pada ujian akhir sekolah maupun pada ujian-ujian lainnya. Berbagai bentuk latihan soal yang dikerjakan siswa didasarkan pada uraian materi yang berfungsi untuk pemantapan keterampilan, pengetahuan, dan sikap (Widodo, 2008). Pada aspek kelengkapan materi, bahan ajar ini telah direvisi dengan menyederhanakan ciri bahasa teks sehingga memudahkan siswa memahami ciri kebahasaan.

Dalam bahan ajar ini berisi kearifan lokal Nusa Tenggara Timur. Kearifan lokal ini terdiri atas tarian, tradisi memelihara dan menjaga alam, tradisi berinteraksi dengan sesama, mahar serta kain adat. Kearifan lokal ini menjadi sarana pembentuk inspirasi bagi siswa dalam menulis teks eksplanasi. Siswa diajarkan untuk selalu peka terhadap kondisi alami yang terjadi sehingga akan semakin tertantang untuk menanggapinya secara kritis, (Wagiran, 2012). Tujuan utama menyusun bahan ajar teks eksplanasi berbasis kearifan lokal adalah mengenalkan budaya kepada siswa. Selain itu, generasi- generasi yang kompeten dimunculkan, bermartabat, mampu merefleksikan nilai-nilai budaya dalam pembentuk karakter bangsa, dan ikut andil dalam melestarikan budaya bangsa. Salah satu cara yang ditempuh dalam mengenalkan kearifan lokal adalah mengintegrasikan kearifan lokal dalam proses pembelajaran (Nadlir, 2014). 


\section{Penyajian Bahan Ajar}

Penyajian bahan ajar ini berisi empat komponen utama yaitu, membangun konteks, pemodelan, latihan terbimbing, dan latihan mandiri. Keempat komponen tersebut diimplikasikan pada setiap kompetensi dasar sesuai kebutuhan siswa. Tahap pembelajaran dalam pendekatan pedagogik genre berlangsung secara bersambungan sehingga apabila pembelajaran sampai pada tahap tertentu dan dilihat belum memadai maka dapat kembali ke tahap sebelumnya (Wiratno, 2018). Penyajian bahan ajar ini pun telah direvisi dan dilengkapi dengan rangkuman, evaluasi dan refleksi.

Membangun konteks dengan menyajikan bacaan-bacaan yang berfungsi untuk menyiapkan siswa dalam mengikuti pembelajaran menulis teks eksplanasi berbasis kearifan lokal. Dalam tahap ini bacaan yang disajikan masih umum seperti pengenalan kearifan lokal Nusa Tenggara Timur. Pada tahap ini, siswa difasilitasi untuk segera beradaptasi dengan alam pikiran sebagaimana yang diterdapat dalam teks yang dijadikan bahan pembelajaran (Wiratno, 2018).

Pemodelan menyajikan contoh teks eksplanasi yang di dalamnya berisi pengaplikasian teori teks ekspalansi. Pemodelan dalam bahan ajar ini terdapat di setiap unit. Pemodelan ini penting karena menyajikan contoh teks yang benar sehingga siswa benar-benar memahami teks eksplanasi. Pada tahap ini, siswa diarahkan pada teks yang ideal untuk dibedah dari sisi struktur dan ciri bahasa yang membentuk teks (Wiratno, 2018).

Latihan terbimbing menyajikan latihan yang masih disertai dengan contoh. Pada tahap ini latihan yang diberikan berupa latihan yang dikembangkan berdasarkan pemodelan. Tujuannya adalah melatih siswa mulai mengerjakan soal sesuai dengan pemahaman terhadap pemodelan. Tahap ini siswa diasumsikan belum dapat menyusun sendiri teks seperti yang dimodelkan sehingga siswa masih perlu menyusunnya secara bersama-sama (Wiratno, 2018). Penyusunan secara bersama ini baik bersama siswa maupun guru.

Latihan mandiri menyajikan latihan-latihan yang berbeda dengan harapan siswa sudah dapat mengerjakan sendiri latihan tersebut sesuai dengan pemodelan. Ukuran keberhasilan pada tahap ini adalah siswa dapat memproduksi teks seperti yang dimodelkan dalam hal struktur teks dan kandungan bentuk-bentuk gramatikal yang seharusnya digunakan (Wiratno, 2018). Selain itu, Latihan yang diberikan berupa latihan yang merangsang siswa menulis seperti melengkapi, mengubah, dan melanjutkan bacaan.

\section{Bahasa Bahan Ajar}

Kajian ini berdasarkan penggunaan bahasa pada setiap komponen dalam bahan ajar. Pada aspek petunjuk latihan telah direvisi sehingga memudahkan siswa mengerjakan latihan. Selain itu, penambahan pengantar kalimat sebelum memberikan pertanyaan atau perintah. Soal latihan harus menggunakan bahasa yang lebih komunikatif. Sehingga tidak menimbulkan distorsi pada siswa. Penggunaan kata kausalitas direvisi dengan sebab akibat karena lebih mudah dipahami oleh siswa. Selain itu kalimat stimulus" setelah kalian belajar menganalisis struktur dan ciri bahas teks eksplanasi, ayo pada unit ini kalian belajar memproduksi teks eksplanasi berdasarkan struktur dan kaidah kebahasaan. Pernahkan kalian menulis teks eksplanasi? namun sebelum kalian belajar menulis teks eksplanasi, bacalah kedua teks berikuti kemudian jawablah pertanyaan yang disediakan." Kalimat-kalimat stimulus tersebut kurang efektif sehingga disarankan menjadi sebelum kalian menulis teks eksplanasi, bacalah kedua teks di bawah ini kemudaian jawablah pertanyaan yang menyertainya. Kalimat singkat, padat, jelas, lengkap dan dapat menyampaikan informasi secara tepat adalah kalimat efektif (Widjono, 2012).

Teks yang dikembangkan dalam bahan ajar disajikan dengan bahasa yang jelas. Selain itu, penggunaan bahasa disesuaikan dengan tingkat kemampuan siswa sehingga mudah diserap pesan yang tersirat dalam teks berbasis kearifan lokal NTT. Kemampuan berpikir, pengalaman, dan lingkungan berpengaruh pada kemampuan penggunaan dan pemahaman bahasa (Sitepu, 2014).

\section{Tampilan Bahan Ajar}

Kajian tampilan bahan ajar berdasarkan desain sampul, ukuran buku, dan desain isi. Pada aspek sampul, bahan ajar ini telah direvisi dengan memperbaiki tata letak gambar yang terdapat dalam sampul. Desain sampul disesuaikan dengan kearifan lokal Nusa Tenggara Timur yang menampilkan kain adat, gading, tarian Kataga dan tarian Gareng. Gambar-gambar tersebut mewakili materi yang terdapat dalam bahan ajar. Selain itu, terdapat judul, nama penulis dan penambahan pada kata siswa pada sampul menunjukkan jenjang bahan ajar ini digunakan.

Pada aspek ukuran buku, kriteria kelayakan ukuran buku telah memadai pada bahan ajar ini. Sesuai dengan standar pencetakan buku Nasional bahwa bahan ajar berstandar ISO berukuran A4 atau B5 sehingga pencetakan setiap bahan ajar menyesuaikan pada standar (Muslich, 2016). A4 adalah ukuran kertas yang dipilih.

Desain isi dalam bahan ajar berbasis kearifan lokal Nusa Tenggara Timur meliputi ukuran, jenis huruf, warna, ilustrasi dan tata letak. Ukuran huruf yang digunakan adalah 12. Pada setiap subunit digunakan Bold. Ukuran 10 digunakan pada keterangan gambar. Huruf yang digunakan adalah kalinga. Warna yang digunakan adalah warna merah dan hijau sesuai dengan karakteristik masyarakat Nusa Tenggara Timur. Selain itu, ilustrasi dalam buku diletakan sesuai teks bacaan dengan tujuan memperjelas bacaan. Penempatan tata letak konsisten berdasarkan pola penyajian, yakni membangun konteks, pemodelan, latihan terbimbing, latihan mandiri, rangkuman, evaluasi, dan refleksi. 


\section{SIMPULAN}

Produk yang dikembangkan telah melalui uji keefektifan dan kelayakan. Uji produk dari ahli menulis, ahli bahan ajar, praktisi, dan siswa. Dalam uji kelayakan diperoleh hasil kelayakan isi sebesar $85 \%$, kelayakan penyajian sebesar $81 \%$, kelayakan bahasa sebesar $80 \%$, dan kelayakan tampilan sebesar $86 \%$. Rata-rata hasil kelayakan produk yang diperoleh dari subjek uji sebesar $83 \%$. Hal tersebut berarti bahan ajar yang dikembangkan layak untuk diimplementasikan. Hasil uji keefektifan produk diketahui bahwa nilai $\mathrm{t}=-7,958$ dan probabilitas sebesar $0,000(\mathrm{p}<0,05)$. Hal tersebut berarti terdapat perbedaan yang signifikan pada kemampuan menulis teks eksplansi sebelum dan setelah menggunakan bahan ajar. Perbedaan yang dimaksud adalah terjadi peningkatan hasil belajar setelah menggunakan bahan ajar sehingga bahan ajar yang dikembangkan efektif untuk diimplementasikan. Berdasarkan hasil iji kelayakan dan keefektifan, bahan ajar yang dikembangkan dapat dijadikan suplemen pembelajaran menulis teks eksplanasi.

Bahan ajar ini dapat dimanfaatkan oleh guru Bahasa Indonesia sebagai acuan dalam mengajarkan materi menulis teks eksplanasi. Selain itu, dapat dimanfaatkan pula oleh guru Mulok dalam mngajarkan kearifan lokal Nusa Tenggara Timur. Bahan ajar ini juga dapat dijadikan sebagai pilihan rujukan dalam menghasilkan latihan-latihan yang variatif. Bahan ajar ini dapat menjadi contoh suplemen pembelajaran yang melengkapi buku paket dari Pemerintah.

Diseminasi dilakukan untuk memperkenalkan bahan ajar teks eksplanasi berbasis kearifan lokal Nusa Tenggara Timur secara luas. Pemanfaatan jurnal penelitian dan pertemuan ilmiah, seperti seminar nasional dan internasional menjadi media untuk memperkenalkan bahan ajar yang kreatif dan inovatif sehingga diperoleh masukan agar lebih baik. Selain itu peneliti akan berkordinasi dengan Dinas Pendidikan Provinsi NTT untuk merevitalisasi budaya Nusa Tenggara Timur dengan memperkenalkan budaya melalui pembelajaran di sekolah.

Terdapat dua saran tambahan, meliputi (1) pemilihan jenis teks. Bahan ajar ini untuk pembelajaran menulis teks eksplanasi sebaiknya peneliti lain mengembangkan jenis teks lain berdasarkan kurikulum. (2) saran tentang kebudayaan yang diintegrasikan pada bahan ajar. Kebudayaan yang diintegrasikan pada bahan ajar ini tidak mencakup keseluruhan kebudayaan NTT sebaiknya peneliti lain dapat menggembangkan produk berdasarkan kebudayaan NTT lainnya.

\section{DAFTAR RUJUKAN}

Akhadiah, S. (1992). Pembinaan Keterampilan Menulis Bahasa Indonesia. Jakarta: Erlangga.

Budi, J. S. (2018). Pengembangan Bahan Ajar Membaca Teks Dongeng Berbasis Kearifan Lokal Malang untuk Siswa Kelas IV Sekolah Dasar. NOSI, 6(1), 1-11.

Darmawan, D. (2012). Inovasi Pendidikan: Pendekatan Praktik Teknologi Multimedia dan Pembelajaran Online. Bandung: PT Remaja Rosdakarya.

Depdiknas. (2008). Pedoman Memilih dan Menyusun Bahan Ajar. Jakarta: Depdiknas.

Kemendikbud. (2017). Model Silabus Mata Pelajaran Sekolah Menengah Atas/Madrasah Aliyah/Sekolah Menengah Kejuruhan/Madrasah Aliyah Kejuruan (SMA/MA/SMK/MAK). Jakarta: Kementerian Pendidikan dan Kebudayaan.

Mascita, D. E., \& Rosmiyati, A. (2018). Pengembangan Bahan Ajar Teks Anekdot Berbasis Kearifan Lokal untuk Siswa Kelas X SMA. Jurnal Tuturan, 7(1), 803-813.

Muslich, M. (2016). Text Book Writing. Yogyakarta: Ar-Ruzz Media.

Nadlir. (2014). Urgensi Pembelajaran Berbasis Kearifan Lokal. Jurnal Pendidikan Agama Islam, 02, 301-330.

Owon, R. A. S. (2017). Pengembangan Bahan Ajar Menulis Berbagai Jenis Teks Bertema Kearifan Lokal Sikka bagi Siswa SMP. JINOP (Jurnal Inovasi Pembelajaran), 3(1), 528-541. https://doi.org/10.22219/jinop.v3i1.4318

Pateda, M. (1989). Analisis Kesalahan. Flores: Nusa Indah.

Rimayanti, A. R., \& Jaja. (2018). Pengembangan Bahan Ajar Teks Eksplanasi Berdasarkan Berita Media Massa Cetak. Jurnal Tuturan, 7(2), 857-862.

Sitepu, B. (2014). Pengembangan Sumber Belajar. Jakarta: Rajawali Press.

Sugiyono. (2016). Metode Penelitian Pendidikan. Bandung: Alfabeta.

Wagiran. (2012). Pengembangan Karakter Berbasis Kearifan Lokal Hamemayu Hayuning Bawana. Jurnal Pendidikan Karakter, 2(3), 329-339.

Widjono, H. (2012). Bahasa Indonesia. Jakarta: Gramedia Widiasarana Indonesia.

Widodo, Chomsin S. Jasmadi. (2008). Panduan Menyusun Bahan Ajar Berbasis Kompetensi. Jakarta: Elex Media Kompetindo. Wiratno, T. (2018). Pengantar Ringkas Linguistik Sistemik Fungsional. Yogyakarta: Pustaka Pelajar. 